\title{
INFLUENCE OF BUSINESS INCUBATORS PERFORMANCE ON ENTREPRENEURIAL INTENTIONS AND ITS ANTECEDENTS DURING THE PRE-INCUBATION STAGE
}

\author{
Karla Roxana Giordano Martínez \\ Tecnológico de Monterrey (México) \\ Telf.: $+818358-2000$ \\ E-mail: kgiordano@itesm.mx \\ Ana Fernández-Laviada* \\ Universidad de Cantabria (Spain) \\ Telf.: +34942201604 \\ Mobile: +34 699507463 \\ E-mail: ana.fernandez@unican.es \\ Ángel Herrero Crespo \\ Universidad de Cantabria (Spain) \\ Telf.: +34942203908 \\ E-mail: angel.herrero@unican.es
}

*corresponding author 


\title{
INFLUENCE OF BUSINESS INCUBATORS PERFORMANCE ON ENTREPRENEURIAL INTENTIONS AND ITS ANTECEDENTS DURING THE PRE-INCUBATION STAGE
}

\begin{abstract}
The pre-incubation phase is critical in the forming of entrepreneur's intention and however it is almost missing in literature. Using the entrepreneurship models based on the beliefs-attitude-intention relationship, a sample of 167 pre-incubated entrepreneurs within the well-known System of Business Incubators of the Monterrey Institute of Technology and Higher Education was surveyed and its statistical analysis developed with Structural Equation Modelling methodology.

Our findings confirm that (1) entrepreneur's perception concerning the incubator's performance directly and positively affects the desirability, self-efficacy and the facilitating conditions, (2) the perceived desirability and feasibility in entrepreneurship, as well as the first ones, self-efficacy and facilitating conditions, positively influence the entrepreneurial intentions. Furthermore, contrary to the traditional mind-set that supports risk is a barrier, results suggest that (3) the risk perceived by pre-incubated entrepreneurs positively influences entrepreneurial intentions and the desirability that is attributed to that behaviour.

Finally, these results also provide insights for organizational leaders and policymakers into managing business incubators and organising their formative programs. The effectiveness of incubators is clear but it is also important to communicate it properly so that incubated individuals can perceive it.
\end{abstract}

\author{
Keywords \\ Entrepreneurial intentions; business incubator; desirability; feasibility; risk perceived; self-efficacy; facilitating \\ conditions.
}

JEL: L26 


\section{Introduction}

Among the public and private policies that support entrepreneurship, it is worth noting the development business incubators have experienced over the last three decades. Just in the United States, the growth from 12 in 1980 to more than 1,400 in 2006, it is a clear indicator (Knopp, 2007). According to Hackett and Dilts (2004a), the phenomenon comes in response to the fact that many governments, local communities and private investors believe it is a good idea to support 'weak' but 'promising' companies by incubating them until they have developed selfsustaining business structures. Therefore, 'business incubators' are thought to be organizations that constitute or create a supportive environment that is conducive to the 'hatching' and development of new firms (Bergek and Norrman 2008). Business incubators provide support throughout the entire business creation process, from the preincubation stage before the company is created (Dickson, 2004), through the post-incubation phase, which is focused on the consolidation of the company (Hackett and Dilts 2004a; Aerts, K., Matthyssens, P., Vandenbempt, K., 2007; Bergek and Norrman 2008).

Voisey et at (2013) argue that the pre-incubation supports nascent entrepreneurs while incubation supports new business because pre-incubators could be defined as “... risk reduced environment where entrepreneurial ideas can be tested for market viability before progressing into the business incubator" (Dickson, 2004). The concept was developed to promote enterprise and spin-out ventures from universities but compare to business incubation remains an under-research topic.

Despite the clear interest awoken by these business incubators during the 1980s (Phan et al. 2005), scientific investigation in this area has been limited up until the last decade (Voisey et al 2006), especially peerreviewed studies that empirically evaluate the impact of business incubation on new venture performance (Amezcua, 2010). In that sense, Ascigil and Magner (2009) show the need to delve deeper in the research into the variables of the incubation process that best explain and diagnose their results. Along those same lines, Schwartz (2011) demonstrates the scarcity of the studies pertain to the effects of the support offered to incubators in the entrepreneurial process and business growth phase.

Incubators offer different types of services that affect the beliefs and attitudes of individuals towards entrepreneurship (Krueger 2001; Peterman and Kennedy 2003; Krueger 2009; Stephens and Onofrei 2012). However, the support services provided by incubators have a different impact depending on the stage of the entrepreneurial process (Hackett and Dilts 2004a; Todorovic and Suntornpithug 2008). In that sense, the majority of 
the studies that focus on the impact of incubation services are centered on the incubation and post-incubation stages (Voisey et al. 2006; Abduh et al.. 2007; Bergek and Norrman 2008; Delmar and Wiklund 2008; Schwartz 2011). However, despite the fact that there are many incubators that offer pre-incubation services (Aerts et al. 2007; Bergek and Norrman 2008), the evidence that is available about their impact on the entrepreneurial process is very limited (Voisey et al. 2013). Therefore, there is a gap in the literature, which is especially relevant since the pre-incubating services are meant to offer would-be entrepreneurs the skills to evaluate their own capabilities and ideas (Grimaldi and Grandi 2005), meaning this stage is critical in the formation of perceptions regarding entrepreneurship and the intentions to create a business (Peterman and Kennedy 2003; Krueger 2009; Stephens and Onofrei 2012).

The empirical results about incubator's performance are quite contradictory. Despite Amezcua's study (2010) raises doubts about the assumed effectiveness of different business models and implementation, others as Barbero et al $(2012,2014)$ find that there are differences depending on their typology, Schwartz and Göthner (2009) and Kilcrease (2011) say the impact of the incubators is determined by the quality of the services their users are provided with, and Rubin et al (2015) suggest that some of their services increase incubatees' financial knowledge and their likehood of raising capital, what improve their outcomes. Likewise, the performance of the entrepreneur not only depends on the type of service the incubator offers them but also on how the service is provided in each phase of the entrepreneurial process (Bergek and Norrman 2008). Hannon and Chaplin (2001) find that a user's perception on the availability and quality of the services influences their evaluation of the incubator's impact on their entrepreneurial project. Therefore, an important aspect to consider in the measurement of a business incubator's impact is the perception of the entrepreneur in regards to the services the incubator provides.

In this context, this paper examines the influence that the entrepreneurs' perceptions about the performance of the incubator and the services provided during the pre-incubation phase have on their intentions to actually create their own business and on other determining variables of entrepreneurial intentions. Specifically, by using the entrepreneurship models based on the beliefs-attitude-intention relationship as a reference (Shapero and Sokol 1982; Krueger and Brazael 1994; Krueger 2009), the effect of the perceived performance in the incubator on desirability and on two feasibility antecedents related to entrepreneurship, self-efficacy (internal factor) and facilitating conditions (external factors), are analyzed. Additionally, the influence the perceived performance of the incubator has on the risk perceived about entrepreneurship is examined. 
Consequently, the main contribution of this research is to deepen the knowledge about the effect incubators' performance during the pre-incubation phase has on the process of business creation and, in particular, about its influence on entrepreneurial intentions and their antecedents. On a theoretical and conceptual level, the consideration of the two feasibility antecedents associated with entrepreneurship, the self-efficacy of the entrepreneur and the facilitating conditions that are reflected in the external factors, can also be considered a contribution.

In the next section, we review the literature and explain the research hypothesis proposed. We then present our sample, the methodological approach and describe the empirical results. Finally, we conclude with our main contributions, and discuss the limitations and implications of this study for further research.

\section{Literature review and research hypothesis}

\subsection{Influence of the perceived desirability and feasibility on entrepreneurial intentions}

As previously stated, in order to uphold this study within a theoretically sound framework, we use entrepreneurship models based on the relationship of belief-attitude-intention as a reference (Shapero and Sokol 1982; Krueger and Brazael 1994; Krueger et al 2000; Krueger 2009). The election of these models is warranted by their acceptance and generalized use to explain entrepreneurial intentions in different areas and contexts, by their apparent explicative nature (Krueger 2009; Schlaegel and Koenig 2014), and by the relevance of the chief explicative variables incorporated in them. Among them, it is important to mention the Entrepreneurial Event Model (Shapero and Sokol 1982), the Entrepreneurial Potential Model (Krueger and Brazael 1994) or Krueger's Model of Entrepreneurial Intentions (Krueger 2009). All of these theoretical models concur in identifying two fundamental explicative variables of entrepreneurial intentions and of entrepreneurial behavior in general: the perceived desirability and perceived feasibility for entrepreneurship.

Shapero and Sokol (1982) define perceived desirability as the degree to which an individual finds starting their own enterprise attractive, which in essence means this concept has an impact on entrepreneurship through its influence on entrepreneurial intentions (Shapero and Sokol 1982; Krueger 1993). Guzmán-Alfonso and GuzmánCuevas (2012) define it as the degree of attraction of starting a new business for a person. Perceived feasibility, on the other hand, is defined as the degree to which an individual believes they are capable of starting a business (Shapero and Sokol 1982). Gasse and Tremblay (2006) state that the entrepreneur not only has to deem 
entrepreneurship as something desirable but they also must recognize it to be reasonably feasible. Therefore, when a person perceives entrepreneurship as being something desirable and actually possible, this creates the intention to take action in an entrepreneurial way (Krueger et al 2000; Elfving et al 2009). Figure 1 summarizes the ShaperoKrueger Model as represented by Krueger et al (2000).

INSERT FIGURE 1 HERE

Several authors have empirically supported the direct influence of perceived desirability and perceived feasibility on entrepreneurial intentions while ignoring the mediating nature of other variables such as the perception of an opportunity or the propensity to act (Krueger et al. 2000; Audet 2002; Veciana et al. 2005). This approach is in line with the Theory of Planned Behavior (Schifter and Ajzen 1985, Ajzen 1991), the most widely applied model of general behavior in the study of entrepreneurship (Liñán and Chen 2009; Finisterra do Paço et al. 2011; Nabi and Liñán 2013; Rueda-Sampedro, M.I. et al. 2014), which states that behavioral intentions are determined directly by the attitude towards behavior and the perceived control of behavior; variables that have been identified as being similar or even identical to perceived desirability (Uygun and Kasimoglu 2013) and perceived feasibility (Finisterra do Paco et al. 2011; Singh et al. 2012), respectively. Consequently, the intentions of incubated entrepreneurs to actually start a business will be determined by the desirability and feasibility they perceive in that behavior.

However, because it is a widely tested model in the literature of entrepreneurship, this study does not include any hypothesis on the causal relations from the variables desirability and feasibility although they are included in our theoretical model and tested empirically.

\subsection{Influence of the perceived risk on entrepreneurial intentions}

Diverse authors have revealed that entrepreneurial behavior is influenced by the perception of risk in the field of entrepreneurship being envisaged as the evaluation of an individual in terms of the potential and probability of loss (Mullins and Forlani 2005; Barbosa et al. 2007; Monsen and Urbig 2009; Nabi and Liñán 2013). In particular, risk traditionally has been considered as something that hampers entrepreneurship so that the perceptions over potential losses derived from business activities would negatively affect entrepreneurial intentions (Kolvereid 1996; Simon et al. 2000; Keh et al. 2002; Janney and Dess 2006). Other authors (Dickson and Giglierano 1986; Barbosa et al. 2007a) have projected that risk can be perceived by entrepreneurs not only as a threat but also as an opportunity 
(associated with the prospective earnings of the new business). However, the empirical support for this approach is still limited, hence this research adopts a conventional conception of perceived risk, and judges that it has a negative influence on entrepreneurial behavior.

H1. The perceived risk in entrepreneurship negatively influences the intention to create a new business.

Despite the fact that risk is a key concept in academic literature about entrepreneurship, very few studies have analyzed its effect on entrepreneurial intentions using as a theoretical framework general entrepreneurial models. Amid the limited research on this topic, Barbosa et al. (2007) and Nabi and Liñán (2013) look at the effect of perceived risk on entrepreneurship behavior, taking the Theory of Planned Behavior as a starting point. Both studies maintain a negative influence of perceived risk on perceived control in entrepreneurial behavior (equivalent to perceived feasibility according to Finisterra do Paco et al. 2011; Singh et al. 2012), but are opposing in regards to its effect on attitudes (equivalent to desirability according to Uygun and Kasimoglu (2013) and entrepreneurial intentions.

The desirability to begin a new business is determined by the entrepreneur's beliefs and perceptions about the positive and negative consequences of that behavior (Shapero and Sokol 1982; Singh et al. 2012). That means desirability is related to certain results or products of entrepreneurship, in terms of the costs and benefits for the entrepreneur (Wilson et al. 2011). In that sense, perceived risk in entrepreneurship embodies the potential consequences or negative results of that type of behavior (Gimeno et al. 1997; Aldrich and Martínez 2001; Monsen and Urbig 2009). In other words, it generates negatives beliefs about entrepreneurship, which negatively influence the desirability associated with that behavior (Fitzsimmons and Douglas 2011; Nabi and Liñán 2013). In keeping with this approach, the following research hypothesis is proposed:

H2. The perceived risk in entrepreneurship negatively influences the perceived desirability of entrepreneurship.

Furthermore, according to Macko and Tyszka (2009) the perceived risk in entrepreneurship is directly related to self-efficacy and the control associated with that behavior (equivalent to perceived feasibility). This perspective is in line with the conclusions of Barbosa et al. (2007b), according to whom perceived risk can produce anxiety and lower levels of self-efficacy and perceived control over the entrepreneurship. Along the same lines, Nabi and Liñán (2013) obtained empirical evidence that backs the negative effect of perceived risk on perceived 
control over the entrepreneurship (equivalent to perceived feasibility). In line with this approach, the following research hypotheses are proposed:

H3. The perceived risk in entrepreneurship negatively influences the perceived feasibility of entrepreneurship.

\subsection{Antecedents of the feasibility of entrepreneurship}

Even though there is no consensus within the literature on entrepreneurship, this research adopts a comprehensive understanding about the perceived feasibility of starting a new business. In particular, two feasibility antecedents are contemplated: self-efficacy (internal component) and the facilitating conditions or contextual factors (external component). This conception about feasibility is backed by the literature on social psychology (Kidwell and Jewell 2010), which says the control perceived in behavior (being equivalent to perceived feasibility, according to Singh et al. (2012) and Uygun and Kasimoglu (2013)) has internal and external components (Conner and Armitage 1998; Armitage et al. 1999). Therefore, contrary to the authors that liken entrepreneurial feasibility to the self-efficacy perceived by the entrepreneur (Krueger 1993; Krueger and Brazael 1994; Guerrero et al. 2008), feasibility would be determined by internal factors (self-efficacy) along with the contextual factors or facilitating conditions (Triandis 1977; Yzer 2012) that may be present.

Therefore, and in accordance with many authors on entrepreneurship (De Noble 1999; Wilson et al. 2007), our study adopts the conception of self-efficacy proposed by Bandura (1997), who defines it as the individual's innermost thoughts on whether they have the abilities perceived as important to task performance, as well as the belief that they will be able to effectively convert those skills into a chosen outcome. Equally, according to Triandis' approach (1977), the facilitating conditions are conceived as the external objective factors that are found in the environment that facilitate the occurrence of a determined type of conduct. This definition is in line with the conception of the facilitating conditions (Birkinshaw 1997) or the contextual factors (Lüthje and Franke 2003) that are proposed within the specific areas related to entrepreneurship.

The difference between these two antecedents of the perceived feasibility is in line with the approach made by Gasse and Tremblay (2006), which shows that feasibility depends on the skills of the entrepreneur as well as the availability or access to the necessary means and resources to start a business. Along those same lines, Veciana et al. (2005) and Fini et al. (2009) observed that perceived feasibility in entrepreneurship is influenced by the availability 
of financial support and other external support mechanisms, such as advisory services or mentoring. As for Serida and Morales (2011), they include the entrepreneur's perceived self-efficacy as well as the necessary resources and/or opportunities to start a business (time, economic resources) within the perceived control over entrepreneurship. Finally, Krueger et al. (2000) say that self-efficacy is an antecedent to perceived feasibility, although they do not include the facilitating conditions in their study. In accordance with the theories of social psychology and with the evidence available on the specific areas of entrepreneurship, the follow research hypotheses are proposed:

H4. The perceived self-efficacy by the entrepreneur exerts a positive influence on the perceived feasibility of entrepreneurship.

H5. The perceived facilitating conditions by the entrepreneur exert a positive influence the perceived feasibility of entrepreneurship.

\subsection{Influence of evaluation of business incubator}

'Business incubators' are conceived as organizations that constitute or create a supportive environment that is conducive to the 'hatching' and development of new firms (Bergek and Norrman 2008). Specifically, incubators offer different types of services that are directed towards promoting the success and survival newly hatched firms through training and the access to external resources and contact networks (Aerts et al. 2007; Bergek and Norrman 2008; Kilcrease 2011; Vanderstraeten and Matthyssens 2012; Voisey et al. 2013). The majority of the authors (Aernoudt 2004; Abduh 2007; Bergek and Norrman 2008; Kilcrease 2011; Rubens et al 2011; Vanderstraeten and Matthyssens 2012) identify four categories of services provided by incubators to companies: a) flexible and subsidized physical spaces, b) business advising, c) making access to financing better and d) networks of formal and informal contacts. Several authors (Krueger 2001; Peterman and Kennedy 2003; Krueger 2007; Stephens and Onofrei 2012) say that training and the entrepreneurial experience significantly affect the beliefs and attitudes of individuals towards entrepreneurship. Therefore, incubating services during the phase before creating the business will affect the perceptions and intentions of the incubated individuals because of the learning effect and experiences.

First of all, through the counselling services and contact networks offered by incubators, individuals are put into contact with other entrepreneurs, mentors and consultants that act as role models (Bollingtoft and Ulhoi 2005; Buche and Scillitoe 2007, Ascigil and Magner 2009). This is, in reality, an environment in which a favorable attitude towards entrepreneurship is introduced, which will lead to it being perceived as a positive professional 
alternative (Fernández-Ballesteros et al. 2002; Kickul 2006) and which increases the perceived desirability of the entrepreneur (Kuehn 2008). So, if the incubated individuals value the performance in the incubator, they will have the perception that the incubator provides a favourable environment for entrepreneurship, which will reinforce the desirability the incubated individuals attribute to that type of behavior. Therefore, the following hypothesis is laid out:

H6. The entrepreneur's perception concerning the incubator's performance in providing services directly and positively affects the perceived desirability of entrepreneurship.

Additionally, the services provided by the business incubators are meant to increase the probabilities of success for the firm (Hackett and Dilts 2004b) and to improve their performance in terms of employment, sales or profitability (Colombo and Delmastro 2002; Delmar and Wiklund 2008; Schwartz 2011). Similarly, Gifford (2010) observes that training services and gaining access to experts increase the information in the decision process and reduce entrepreneurial risk. What is more, the possibility of accessing shared resources at a low cost (Voisey et al. 2006; Stephens and Onofrei 2012) reduces the investment the entrepreneur has to make, which makes the risks to be assumed fewer in number (Petrakis, 2005). Furthermore, Wirsing et al. (2002) show that pre-incubation services allow entrepreneurs to test their business idea, thereby reducing the risks of starting a business. That means the incubated individuals should perceive less risk in creating their businesses, at least in the sense that they positively value the services offered by the incubator. In line with this approach, the following hypothesis is set forth:

H7. The entrepreneur's perception concerning the incubator's performance in providing services directly and negatively affects the perceived risk of entrepreneurship.

In relation to the antecedents of perceived feasibility in entrepreneurship, the business incubators provide services that are directed at increasing the self-efficacy of the entrepreneur during the process of creating the business. Specifically, counselling on business management and the mentoring by other entrepreneurs (Aernoudt 2004; Abduh 2007; Bergek and Norrman 2008; Kilcrease 2011; Rubens et al. 2011; Schwartz 2011; Vanderstraeten and Matthyssens 2012) allow the entrepreneur to access business knowledge, a variable that is been identified as an antecedent or precursor to self-efficacy (Fayolle and Degeorge 2006). Similarly, Voisey et al. (2006) and Stephens and Onofrei (2012) show that business incubators create, among other things, an increase in the entrepreneur's professionalism, an improvement in business management skills and an increase on one's self confidence. More specifically, Wirsing et al. (2002) say that pre-incubation services allow entrepreneurs to receive training and 
business counselling and to obtain business experience before they start off their business. As a consequence, a positive evaluation of the incubator's performance will indicate that the incubated individuals perceive they are being given counselling and knowledge that is useful for entrepreneurship, thereby reinforcing the self-efficacy to carry out that type of behavior. Therefore, the following hypothesis is suggested:

H8. The entrepreneur's perception concerning the incubator's performance in providing services directly and positively affects the perceived self-efficacy in entrepreneurship.

Along those same lines, one of the main functions of the business incubators is to facilitate access to physical installations, financing, technological infrastructures and contact networks that are useful in the development of the company (Aernoudt 2004; Kilcrease 2011; Schwartz 2011). In that sense, Abduh et al. (2007) observe that entrepreneurs believe that flexible and low-cost spaces and the installations offered by the incubators are the most valuable services for the development of their companies. As for Voisey et al. (2006) and Stephens and Onofrei (2012), they say business incubators favor networking (social capital) and access to resources at lower costs, both of which increase the facilitating conditions for entrepreneurship. Therefore, the evaluation of the incubator's performance will be positive to the extent that the entrepreneurs perceive that the incubator is making the access to the necessary external resources easier in order to carry out their initiatives, thereby positively influencing their perceptions towards the facilitating conditions of creating a business. Therefore, the following hypothesis is set forth:

H9. The entrepreneur's perception concerning the incubator's performance in providing services directly and positively affects the perceived facilitating conditions for entrepreneurship.

The research hypotheses that have been set forth are used to make the research model that is shown in Figure 2. INSERT FIGURE 2 HERE

\section{Research methodology}

In order to empirically contrast the research hypotheses that were set forth, a quantitative investigation was made with the entrepreneurs integrated in the pre-incubation phase within the business incubators of the Monterrey Institute of Technology and Higher Education, a leading academic institution in Latin America in training and support for entrepreneurship. 
The information was brought together using a structured questionnaire in which the variables involved in the theoretical model were measured with multi-item scales (Appendix 1). This makes it possible to obtain estimations of psychological variables that cannot be measured directly (Churchill and Iacobucci 2002). The variables were measured using Likert scales of five positions $(1=$ strongly disagree with the affirmation made and 5 $=$ strongly agree). The mechanisms used to measure entrepreneurial intentions and the desirability and feasibility associated with that behavior were adapted from the studies of Liñán and Chen (2009) and Finisterra do Paço et al. (2011). The scales of perceived risk were adapted from the proposals of Barbosa et al. (2007b). The instrument to measure self-efficacy was adapted from DeNoble et al. (1999) and Kickul (2006), while the scale for facilitating conditions was established based on the proposals by Edelman and Yli-Renko (2010). Lastly, the way in which to measure the perceived performance of the business incubators stemming from their provision of services has been developed based on the proposals by Meru and Struwig (2011).

To acquire the sample of incubated companies, the survey questionnaire was sent by e-mail to 1,306 individuals who were participating in entrepreneurial pre-incubation within the Monterrey Institute of Technology and Higher Education. Those entrepreneurs that did not complete the survey were telephoned in order to get a response. The response rate was $18.57 \%$ while obtaining a total of 167 usable responses in the end. Table 1 shows the socio-demographic profile of the nascent entrepreneurs sample utilized in this study.

INSERT TABLE 1 HERE

\section{Results}

The statistical analysis has been developed using Structural Equation Modelling (SEM) methodology, with the program EQS 6.1. First, the psychometric properties of the measurement scales (reliability and validity) were verified using a Confirmatory Factor Analysis (CFA). Next, the causal model was assessed in order to contrast the research hypotheses.

A preliminary Confirmatory Factor Analysis shows the need to remove the item FEA4 from the feasibility scale, due to discriminant validity problems (excessive loading on other factors). Once this correction was made, the results obtained for the goodness-of-fit indexes display an accurate specification for the measurement model. In particular, there are three main classes of goodness-of-fit criteria: measures of absolute fit, measures of incremental fit, and measures of parsimonious fit (Hair et al. 1998). In this case, we use the data provided by EQS 6.1, which is 
widely used in the SEM literature (Hair et al. 1998): Bentler-Bonett Non-Normed Fit Index (BBNNFI) and Root Mean Square Error of Approximation (RMSEA) for the measurement of overall model fit; Incremental Fit Index (IFI) and Comparative Fit Index (CFI) as measures of incremental fit; and Normed $\chi 2$ for the measurement of the parsimony of the model. More specifically, the results summarized in Table 2 ratify that the BBNNFI, IFI, and CFI statistics surpass the recommended minimum value of 0.9 , while RMSEA is positioned below the maximum limit of 0.08 , and Normed $\chi 2$ takes a value unmistakably under the recommended value of 3 (Hair et al., 1998).

\section{INSERT TABLE 2 HERE}

The reliability of measurement scales is assessed from the Cronbach's Alpha, compound reliability and AVE coefficients (Bagozzi and Yi 1988). It is clear that to see the values of these statistics are, in every case, evidently above the required minimum values of 0.7 and 0.5 respectively (Nunally 1978; Hair et al. 1998), which backs the inner reliability of the proposed constructs (Table 2). The convergent validity of the scales is also verified (Table 2), since all items are significant at a confidence level of $95 \%$ and their standardized lambda coefficients are higher than 0.5 (Steemkamp and Van Trijp 1991). The discriminant validity of the scales is verified following the techniques proposed by Anderson and Gerbing (1988) and Fornell and Larcker (1981). According to Anderson and Gerbing (1988), the discriminant validity of the scales is sustained, as none of the confidence intervals for the correlation among factors contains value 1 (Table 3). The approach proposed by Fornell and Larcker (1981) also confirms the discriminant validity of the scales, since the shared variances between pairs of construct are always lower than the AVE of each construct (Table 4).

The descriptive statistics of the model's variables are summarized in Appendix 2.

\section{INSERT TABLE 3 Y 4 HERE}

When the psychometric properties of the scales were scrutinized, the proposed causal model was calculated using the Robust Maximum Likelihood estimation procedure to control non-normality of the data. The results obtained in the estimation of the proposed research model (Figure 3) show that incubated companies' entrepreneurial intentions are positively and directly influenced by the perceived desirability and feasibility and the perceived risk (H1) in creating a new business. Perceived risk has a positive influence on perceived desirability (H2) as well, but does not have a significant effect on perceived feasibility (H3). The results obtained with respect to the influence of the perceived risk on intentions and desirability have the opposite outcome from the $\mathrm{H} 1$ and $\mathrm{H} 2$ hypotheses. Therefore, in accordance with the empirical evidence obtained, the bigger the perceived risk is, the 
greater the entrepreneurial intentions and desirability are towards that type of behavior for the incubated entrepreneurs. These results can be justified for the conception of risk as an opportunity (Dickson and Giglierano 1986; Barbosa et al. 2007a), which says that the risk perceived is an indicator of the potential benefits of starting a new business. Additionally, according to the empirical evidence obtained perceived risk does not exert a significant effect on perceived feasibility, which reinforces the finding that nascent entrepreneurs perceive risk more as an indicator of opportunities than as a barrier for creating a new business. Moreover, the effect of perceived risk on feasibility could be inhibited due to explicitly considering other explanatory variables related to restrictions or facilitators to entrepreneurship such as self-efficacy and the facilitating conditions available.

\section{INSERT FIGURE 3 HERE}

The results obtained in our research show that perceived feasibility in entrepreneurship is positively influenced by entrepreneurs' perceptions about self-efficacy $(\mathrm{H} 4)$ and the existing facilitating conditions to carry it out (H5). More specifically, it's worth mentioning that despite some authors (Krueger 1993; Krueger and Brazael 1994; Guerrero et al. 2008) assume the concepts of feasibility and self-efficacy, the facilitating conditions have a more intense effect on perceived feasibility than perceived self-efficacy. Therefore, our results confirm the difference between feasibility and self-efficacy and manifest the need to incorporate the facilitating conditions into the models on entrepreneurial intentions.

Finally, the empirical evidence obtained demonstrates that users' perceptions about the performance of the incubators providing their services positively affects desirability (H6), self-efficacy (H8) and the facilitating conditions (H9). Contrarily, a significant influence is not observed on the perceptions about the performance of the incubators concerning perceived risk (H7). These results determine that the services provided by business incubators reinforce the predisposition of the incubated individuals to start their own business. Furthermore, the incubated individuals believe the incubators contribute to increasing their self-efficacy in creating the business and improve the conditions to carry the process out through access to technological resources, funding and business networks. However, they do not contribute to reduce the perception of risk, which in any case acts more as an incentive than as a deterrent to entrepreneurship, as it has been previously mentioned. Accordingly, a better performance of the incubator may not reduce risk perception in creating a new business, because for nascent entrepreneurs perceived risk is more an encouragement (indicator of future opportunities) than a barrier for entrepreneurship. 


\section{Conclusions}

Taking the entrepreneurship models based on the beliefs-attitude-intention relation (Shapero and Sokol 1982; Krueger and Brazael 1994; Krueger 2009) as a reference, this research examines the effect that incubator performance has during the pre-incubation phase on entrepreneurial intentions and its antecedents. More specifically, the results that were obtained confirm that perceived desirability and feasibility in entrepreneurship positively influence the incubated individuals' intentions to start their own business. Also, the risk perceived by the incubated individuals is observed to have a positive influence on entrepreneurial intentions and on the desirability attributed to those actions. Furthermore, it is been confirmed that perceived feasibility of the business initiative is positively influenced by the incubated individuals' perceptions with respect to self-efficacy and the facilitating conditions to start their own business. Finally, the empirical evidence that has been obtained supports the positive effect of the perceived performance of the business incubators during the pre-incubation stage on the desirability attributed to that behavior and on self-efficacy and the facilitating conditions to start their own business.

The results of this research provide various relevant conclusions with respect to the previous academic literature. First of all, this paper contributes to the limited amount of empirical evidence on the effects of incubator services in the entrepreneurship process (Schwartz 2011). Specifically, this research is focused on the stage before the creation of a company and adopts an approach that is based on the perspective of the entrepreneur, which is barely explored in the available literature (Hannon 2005; Meru and Struwig 2011). In that sense, it has been confirmed that the performance of the business incubators has a favorable influence on the entrepreneurial process during the pre-incubation stages, which reinforces the incubated individuals' perceptions with respect to desirability, self-efficacy and the facilitating conditions to start a business. In accordance with these results, and coinciding with the approaches of Fernández-Ballesteros et al. (2002), Kickul (2006) or Kuehn (2008), the social environment favorable to entrepreneurship that is provided by incubators fosters the desirability attributed to this type of behavior by entrepreneurs. At the same time, along the lines of the results of Stephens and Onofrei (2012), the counselling services and the access to resources and contact networks have an influence on the self-efficacy perceived by the incubated individuals and on the perception about the most favorable facilitating conditions to start a business.

This study also supposes a contribution on a theoretical and conceptual level from the identification of two antecedents of the feasibility that are associated with entrepreneurship: the self-efficacy of the individual and the facilitating conditions to start a business. Therefore, compared to the theoretical approaches that liken feasibility to 
self-efficacy (Krueger 1993; Krueger and Brazael 1994; Guerrero et al. 2008) or only consider self-efficacy to be an antecedent to feasibility (Krueger, 2009), our results confirm that feasibility is also determined by the perceived facilitating conditions. Furthermore, the empirical evidence obtained shows that perception about the facilitating conditions has a stronger effect on feasibility than self-efficacy.

Another finding that has relevant implications to entrepreneurship theory is related to the effect of the perceived risk. In that sense, in contrast to the traditional approach, which conceives risk as a barrier or impediment to entrepreneurship (Kolvereid 1996; Simon et al. 2000; Keh et al. 2002; Janney and Dess 2006), according to the empirical evidence obtained, perceived risk has a positive effect on entrepreneurial intentions and the desirability attributed to this type of behavior in incubated individuals. These results support the conceptualization of risk as an opportunity (Dickson and Giglierano 1986), which means that entrepreneurs would associate the risk with the potential benefits when create a business. As a consequence, seeing risk as an opportunity would have a positive influence on entrepreneurial intentions (Barbosa et al. 2007a) or on the perceived desirability to start a business (Nabi and Liñán 2013).g

The results of this research also have relevant implications from an applied point of view, especially for the management of business incubators. Firstly, the effectiveness of these types of organizations to provide incentives and facilitate the creation of new companies is confirmed (Bergek and Norman 2008), which justifies investment in business incubators on a public as well as private level. Moreover, from a business incubator management point of view, evidence is found on the relevance of the different types of services provided (Kilcrease 2011; Vanderstraeten and Matthyssens 2012) in order to reinforce entrepreneurial intentions during the pre-incubation stage. In that sense, and in line with previous literature (Bollingtoft and Ulhoi 2005, Ascigil and Magner 2009), the business incubators need to provide a social environment that is favorable to entrepreneurship by facilitating the contact with professionals, counsellors and mentors who reinforce the entrepreneurs' perceived desirability to start a business depending on its feasibility and opportunity. Furthermore, our results show that incubators have to provide counselling and training services that increase the perceived self-efficacy by the incubated individuals (Voisey et al 2006) as well as access services to find resources that improve the facilitating conditions to start a business. Finally, our study is focused on the perceptions of the incubated individuals, which means that an adequate management of an incubator not only requires good performance in the provision of these services but it also has to be 
communicated and explained correctly to its users. That means it's necessary to establish the correct types of information mechanisms so that incubates can truly feel the quality of the services provided to them.

To conclude, it is necessary to mention that in spite of the systematic methodology followed throughout the development of this paper, the research that was carried out does present some limitations. First, this study is focused on Mexico and specifically on the business incubator system of the Monterrey Institute of Technology and Higher Education, which could limit the generalization of the results. However, it would be interesting to replicate the research in other geographical areas in order to examine potential cross-cultural differences. Furthermore, according to GEM (2014), Mexico is highly representative of the Latin American countries regarding entrepreneurship. Additionally, the Monterrey Institute of Technology and Higher Education was chosen as a reference because it is a leading academic institution in Latin America in training and support for entrepreneurship. Moreover, this study takes entrepreneurial intentions as a dependent variable, but it does not examine the actual entrepreneurial behavior. This is to say, it does not measure a posteriori if entrepreneurial intentions are actually leading to the creation of a new business. In that sense, it would be interesting to examine the actual entrepreneurial behavior of the subjects in future research.

\section{References}

Abduh, M., D’Souza, C., Quazi, A., Burley, H.T., 2007. Investigating and classifying clients' satisfaction with business incubator services. Managing Service Quality, 17(1), 74-91.

Aernoudt, R., 2004. Incubators: tool for entrepreneurship? Small Business Economics, 23, 127-135.

Aerts, K., Matthyssens, P., Vandenbempt, K., 2007. Critical role and screening practices of European business incubators. Technovation, 27(5), 254-267.

Ajzen, I., 1991. The theory of planned behavior. Organizational Behavior and Human Decision Processes, 50(2), $179-211$.

Aldrich, H.E., Martinez, M.A., 2001. Many are called, but few are chosen: An evolutionary perspective for the study of entrepreneurship. Entrepreneurship Theory and Practice, 25(4), 41-56.

Amezcua, A.S. 2010. Boon or Boondoggle? Business Incubation as Entrepreneurship Policy. Syracuse University. 
Anderson, J.C., Gerbing, D.W., 1988. Structural equation modelling in practice: A review and recommended twostep approach. Psychological Bulletin, 103(3), 411-423.

Armitage, C.J., Conner, M., Loach, J., Willetts, D., 1999. Different perceptions of control: Applying an extended theory of planned behavior to legal and illegal drug use. Basic and Applied Social Psychology, 21(4), 301-316.

Ascigil, S.F., Magner, N.R., 2009. Business incubators: Leveraging skill utilization through social capital. Journal of Small Business Strategy, 20(1), 19-34.

Audet, J. 2002. A longitudinal study of the entrepreneurial intentions of university students. Working paper presented at the Babson Kaufmann Entrepreneurship Research Conference in Boulder, Colorado.

Bagozzi, R. P., Yi, Y., 1988. On the evaluation of structural equation models. Journal of the Academy of Marketing Science, 16(1), 74-94.

Bandura, A. 1997. Self-efficacy: The exercise of control. New York: W. H. Freeman.

Barbero, J.L., Casillas, J.C., Ramos, A. and Guitar, S. 2012. Revisiting incubation performance. How incubator typology affects results. Technological Forecastin \& Social Change, 79, 888-902.

Barbero, J.L., Casillas, J.C., Wright, M. and Ramos, A. 2014. Do different types of incubators produce different types of innovations? Journal Technology Transfer (39), 151-168.

Barbosa, S.D., Gerhardt, M.W., Kickul, J.R., 2007. The Role of Cognitive Style and Risk Preference on Entrepreneurial Self-Efficacy and Entrepreneurial Intentions. Journal of Leadership and Organizational Studies, 13(4), 86-104.

Barbosa, S.D, Kickul J., Liao-Troth, M., 2007. Development and validation of a multidimensional scale o entrepreneurial risk perception. Annual Meeting of the Academy of Managemente, Academy of Management, Philadelphia, PA.

Bergek, A., Norrman, C., 2008. Incubator best practice: A framework. Technovation, 28(1/2), 20-28.

Birkinshaw, J., 1997. Entrepreneurship in multinational corporations: The characteristics of subsidiary initiatives. Strategic Management Journal, 18(3), 207-229. 
Bøllingtoft, A., Ulhøi, J.P., 2005. The networked business incubator-leveraging entrepreneurial agency? Journal of business venturing, 20(2), 265-290.

Buche, M.W., Scillitoe, J.L., 2007. Influence of gender and social networks on organizational learning within technology incubators. American Journal of Business, 22(1), $59-68$.

Churchill, G.A., Iacobucci, D., 2002. Marketing Research Methodological Foundations. 8th edition. Thomson, Mason.

Colombo, M.G., Delmastro, M., 2002. How effective are technology incubators?: Evidence from Italy. Research Policy, 31(7), 1103-1122.

Conner, M., Armitage, C.J., 1998. Extending the theory of planned behavior: A review and avenues for further research. Journal of Applied Social Psychology, 28(15), 1429-1464

De Noble, A., Jung, D., Ehrlich, S., 1999. Entrepreneurial self-efficacy: The development of a measure and its relationship to entrepreneurial action. In R.D. Reynolds et al. Eds. Frontiers of entrepreneurship research, 73-78. Waltham, MA: P y R Publication Inc.

Delmar, F., Wiklund, J., 2008. The effect of small business managers' growth motivation on firm growth: A longitudinal study. Entrepreneurship Theory and Practice, 32(3), 437-457.

Dickson, P.R., Giglierano, J.J., 1986. Missing the boat and sinking the boat: A conceptual model of entrepreneurial risk. Journal of Marketing, 50(3), 58-70.

Dickson, A. 2004. Pre-incubation and the New Zeland business incubator industry. Report for incubators New Zealand, available at: http://www.incubators.org/content/news.

Edelman, L., Yli-Renko, H., 2010. The impact of environment and entrepreneurial perceptions on venture-creation efforts: Bridging the discovery and creation views of entrepreneurship. Entrepreneurship: Theory \& Practice, 34(5), 833-856

Elfving, J., Brännback, M., Carsrud, A., 2009. Toward a contextual model of entrepreneurial intentions. In Understanding the entrepreneurial mind, 23-33. Springer New York. 
Fayolle, A., Degeorge, J.M., 2006. Attitudes, intentions, and behaviour: New approaches to evaluating entrepreneurship education. International entrepreneurship education. Issues and newness, 74-89.

Fernández-Ballesteros, R., Díez-Nicolás, J., Caprara, G.V., Barbaranelli, C., Bandura, A., 2002. Determinants and Structural Relation of Personal Efficacy to Collective Efficacy. Applied Psychology, 51(1), 107-125.

Fini, R., Grimaldi, R., Sobrero, M., 2009. Factors fostering academics to start up new ventures: an assessment of Italian founders' incentives. The Journal of Technology Transfer, 344, 380-402.

Finisterra do Paço, A.M., Matos, J., Raposo, M., Gouveia, R., Dinis, A., 2011: Behaviours and entrepreneurial intention: empirical findings about secondary students. Journal International Entrepreneurship, 9, 20-38.

Fitzsimmons, J., Douglas, E., 2011. Interaction between feasibility and desirability in the formation of entrepreneurial intentions. Journal of Business Venturing, 26(4), 431-440.

Fornell, C., Larcker, D.F., 1981. Evaluating structural equation models with unobservable variables and measurement error. Journal of Marketing Research, 18(1), 39-50.

Gasse, Y., Tremblay, M., 2006. Entrepreneurship education among students at a Canadian university: An extensive empirical study of students' entrepreneurial preferences and intentions. International Entrepreneurship Education: Issues and Newness, 241-262.

Gimeno, J., Folta, T.B., Cooper, A.C., Woo, C.Y., 1997. Survival of the fittest? Entrepreneurial human capital and the persistence of underperforming firms. Administrative science quarterly, 750-783.

Grimaldi, R., and Grandi, A., 2005. Business incubators and new venture creation: an assessment of incubating models. Technovation, 25, 111-121

Guerrero, M., Rialp, J., Urbano, D., 2008. The impact of desirability and feasibility on entrepreneurial intentions: a structural equation model. International Entrepreneurship and Management Journal, 4(1), 35-50.

Guzmán-Alfonso, C., Guzmán-Cuevas, J., 2012. Entrepreneurial intention models as applied to Latin America. Journal of Organizational Change Management, 25(5), 721-735.

Hackett, S., Dilts, D., 2004a. A real options-driven theory of business incubation. The Journal of Technology Transfer, 29(1), 41-54. 
Hackett, S., Dilts, D., 2004b. A systematic review of business incubations research. The Journal of Technology Transfer 29(1), 55-82.

Hair, J.F., Anderson, R.E., Tatham, R.L., W.C. Black, 1998. Multivariate data analysis. 5th edition. New Jersey: Prentice Hall.

Hannon, P., 2005. Incubation policy and practice: building practitioner and professional capability. Journal of Small Business and Enterprise Development, 12(1), 57-75.

Hannon, P., Chaplin, P., 2001. The UK Incubation Impact Assessment Study: Identification of Best Practice, UKBI, Birmingham.

Janney, J., Dess, G., 2006. The risk concept for entrepreneurs reconsidered: New challenges to the conventional wisdom. Journal of Business Venturing, 21, 385-400.

Keh, H.T., Foo, M.D., Lim, B.C., 2002. Opportunity evaluation under risky conditions: The cognitive processes of entrepreneurs. Entrepreneurship: Theory \& Practice, 27(2), 125-148.

Kidwell, B., Jewell, R., 2010. The motivational impact of perceived control on behavioral intentions. Journal of Applied Social Psychology, 40(9), 2407-2433.

Kickul, J., 2006. Pathways to new business opportunities: innovations and strategies for the entrepreneurial classroom. International Entrepreneurship Education: Issues and Newness, 168-182.

Kilcrease, K.M., 2011. Multi-factor assessment of service delivery in business incubators: Perspectives from incubator tenents. Journal of Applied Management and Entrepreneurship, 16(2), 80-95.

Knopp, L. 2007. 2006 State of the business in the United States. Cambrige, Mass: MIT Press.

Kolvereid, L., 1996. Prediction of employment status choice intentions. Entrepreneurship Theory and Practice, 21(1), 47-58.

Krueger N.F., 1993. The impact of prior entrepreneurial exposure on perceptions of new venture feasibility and desirability. Entrepreneurship Theory and Practice, 18(1), 5-21.

Krueger N.F., 2009, Entrepreneurial intentions are dead: long live entrepreneurial intentions, en Carsrud, A., Brännback, M. ed Understanding the Entrepreneurial Mind: Opening the Black Box, 51-72. Nueva York: Springer 
Krueger N.F., Brazael, D. 1994. Entrepreneurial Potential and Potential Entrepreneurs. Entrepreneurship: Theory \& Practice 18(3), 91-104.

Krueger N.F., Reilly, M.D., Carsrud, A.L., 2000. Competing Models of Entrepreneurial Intentions. Journal of Business Venturing, 15(5/6), 411-432.

Kuehn, K., 2008. Entrepreneurial Intentions Research: Implications for Entrepreneurship Education. Journal of Entrepreneurship Education, 11, 87-98.

Liñán, F., Chen, Y., 2009. Development and cross-cultural application of a specific instrument to measure entrepreneurial intentions. Entrepreneurship: Theory \& Practice, 33(3), 593-617.

Lüthje, C., Franke, N., 2003. The making of an entrepreneur: Testing a model of entrepreneurial intent among engineering students at MIT. Research and Development Management, 32, 135-147.

Macko, A., Tyszka, T., 2009. Entrepreneurship and Risk Taking. Applied Psychology, 58(3), 469-487.

Meru, A., Struwig, M., 2011. An evaluation of the entrepreneurs' perception of business-incubation services in Kenya. International Journal of Business Administration, 2(4), 112-121.

Monsen, E., Urbig, D., 2009. Perceptions of efficacy, control and risk: A theory of mixed control. In A. Carsrud, M. Brännback Eds., Understanding the entrepreneurial mind. New York: Springer.

Mullins, J., Forlani, D., 2005. Missing the boat or sinking the boat: a study of new-venture decision-making. Journal of Business Venturing 20(1), 47-69.

Nabi, G., Liñán, F., 2013. Considering business start-up in recession time: The role of risk perception and economic context in shaping the entrepreneurial intent. International Journal of Entrepreneurial Behaviour and Research, 19(6), 633-655.

Nunally, J.C., 1978. Psychometric Theory 2nd Edition. McGraw Hill.

Peterman, N.E., Kennedy, J., 2003. Enterprise education: Influencing students’ perceptions of entrepreneurship. Entrepreneurship Theory and Practice, 28(2), 129-144.

Petrakis, P.E., 2005: Risk Perception, risk propensity and entrepreneurial behaviour: the Greek case. Journal of American Academy of Business, 7(1), 233-242 
Phan, P., Siegel, D., Wright, M., 2005. Science parks and incubators: observations, synthesis and future research. Journal of Business Venturing, 20(2), 165-182.

Rubens, A., Jackson, G., Andrews, C., 2011. Conducting a feasability analysis and assessing success of a business incubator: An applied study. Journal of Applied Management and Entrepreneurship, 16(2), 42-60.

Rubin, T.H, Aas, T.H and Stead, A. 2015. Knowledge flow in Technological Business Incubators: evidence from Australia and Israel. Technovation (41-42), 11-24.

Rueda-Sampedro, M.I., Fernández-Laviada, A., Herrero-Crespo, A., 2014 Entrepreneurial intention: Perceived advantages and disadvantages. Academia Revista Lationamericana de Administración, 27(2), 284-315

Schifter, D.B., Ajzen, I., 1985. Intention, perceived control, and weight loss: an application of the theory of planned behaviour. Journal of Personality and Social Psychology, 49, 842-851.

Schlaegel, C., Koenig, M., 2014. Determinants of entrepreneurial intent: A meta-analytic test and integration of competing models. Entrepreneurship Theory and Practice, 38(2), 291-332.

Schwartz, M., 2011. Incubating an illusion? Long-term incubator firm performance after graduation. Growth and Change, 424, 491-516.

Schwartz, M., Göthner, M., 2009. A multidimensional evaluation of the effectiveness of business incubators: an application of the PROMETHEE outranking method. Environment and Planning C: Government and Policy, 27, 1072-1087.

Serida, J., Morales, O., 2011 Using the theory of planned behavior to predict nascent entrepreneurship. Academia, Revista Latinoamericana de Administración, 46, 55-71.

Shapero, A., Sokol, L., 1982. Social dimensions of entrepreneurship. In C. Kent, D. Sexton, K. Vespers Eds, The Encyclopedia of Entrepreneurship: Prentice-Hall: Englewood Cliffs, NJ 72-90.

Simon, M., Houghton, S.M., Aquino, K., 2000. Cognitive biases, risk perception and venture formation: How individuals decide to start companies. Journal of Business Venturing, 15(2), 113-134.

Singh, I., Prasad, T., Raut, R., 2012: Entrepreneurial intent-A review of literature. Ninth AIMS International Conference on Management, January 1-4. 
Steenkamp, J.B., Van Trijp, H.C. M., 1991. The use of LISREL in validating marketing constructs. International Journal of Research in Marketing, 8, 283-299.

Stephens, S.; Onofrei, G., 2012. Measuring business incubation outcomes: An Irish case study. The International Journal of Entrepreneurship and Innovation, 13(4), 277-285.

Todorovic, Z., Suntornpithug, N. 2008. The Multi-Dimensional Nature of University Incubators:

Capability/Resource Emphasis Phases. Journal of Enterprising Culture 16(4), 385-410.

Triandis , H.C., 1977. Interpersonal behavior. Monterey, CA: Brooks/Cole.

Uygun, R., Kasimoglu, M., 2013. The emergence of entrepreneurial intentions in indigenous entrepreneurs: The role of personal background on the antecedents of intentions. International Journal of Business and Management, 8(5), 24-40.

Vanderstraeten, J., Matthyssens, P., 2012. Service-based differentiation strategies for business incubators: Exploring external and internal alignment. Technovation, 32(12), 656-670.

Veciana, J.M., Aponte, M., Urbano, D. 2005, University student's attitudes towards entrepreneurship: a two countries comparison. International Entrepreneurship and Management Journal, 1, 165-182.

Voisey, P., Gornall, L., Jones, P., 2006. The measurement of success in a business incubation project. Journal of Small Business and Enterprise Development, 13(3), 454-468.

Voisey, P.; Jones, P.; Thomas, B., 2013. The pre-incubator: a longitudinal study of 10 years of university preincubation in Wales. Industry and Higher Education, 27(5), 349-363.

Wilson, F., Kickul, J., Marlino, D., 2007. Gender, Entrepreneurial Self-Efficacy, and Entrepreneurial Career Intentions: Implications for Entrepreneurship Education. Entrepreneurship theory and practice, 31(3), 387-406.

Wirsing, B.; Traude, A.; Steffens, J.; Sheen, M.; Löffler, B.; De Lapparent, D.; Broadfoot, C.; Alonso-Gonzalez, J.L., 2002. Becoming an entrepreneur for a trial period: The pre-incubation experience. The International Journal of Entrepreneurship and Innovation, 3(4), 265-277.

Yzer, M., 2012. Perceived Behavioral Control in Reasoned Action Theory A Dual-Aspect Interpretation. The ANNALS of the American Academy of Political and Social Science, 640(1), 101-117 
1

2

3

4

5

6

7

8

9

10

11

12

13

14

15

16

17

18

19

20

21

22

23

24

25

26

27

28

29

30

31

32

33

34

35

36

37

38

39

40

41

42

43

44

45

46

47

48

49

50

51

52

53

54

55

56

57

58

59

60
Zellweger, T., Sieger, P., Halter, F., 2011. Should I stay or should I go? Career choice intentions of students with family business background. Journal of Business Venturing, 26(5), 521-536. 


\section{Appendix 1}

\section{Entrepreneurial Intention}

INT1. I have the clear intention to create my own business in less than one year.

INT2. My professional objective is to create my own business in less than one year.

INT3. I am determined to create my own business in less than one year.

INT4. I will do anything possible to create my own business in less than one year.

Desirability

DES1. The idea of creating my own business seems attractive to me.

DES2. The idea of creating my own business really appeals to me.

DES3. Creating my own business would be a huge satisfaction for me.

DES4. My calling is to create my own business.

Feasibility

FEA1. Creating a business in less than one year would be easy for me.

FEA2. It's very feasible to create my own business in less than one year.

FEA3. For me it will be simple to create my own business in less than one year.

FEA4. I'm in a good position to create my own business in less than one year.

\section{Perceived Risk}

RSK1. Creating a business is very risky.

RSK2. The probability that the new business fails is very high.

RSK3. There is a lot of uncertainty around the success of a newly created business.

RSK4. A lot of risks exist that are associated with the creation of a new business.

\section{Self-efficacy}

SEF1. I believe I am capable of developing innovative ideas and products.

SEF2. I can identify new market opportunities for innovative products and services.

SEF3. I am able to discover new forms of existing products.

SEF4. I am capable of identifying business opportunities with growth potential.

SEF5. I am able to react rapidly to take advantage of business opportunities.

SEF6. I believe I am capable of creating new products that satisfy customers' unsatisfied needs.

SEF7. I can design a plan of action to take advantage of business opportunities.

\section{Facilitating conditions}

FCO1. The minimum capital necessary to create a business can be accessed easily.

FCO2. It's easy to find the necessary contacts to be able to take a business forward.

FCO3. It's easy to gain access to experts to develop a new business.

FCO4. I could easily get access to specialised counselling in a sector of specific activity.

FCO5. It's easy to share experiences with successful entrepreneurs in order to develop a business.

FCO6. It's easy to access physical spaces (offices, meeting rooms, laboratories, etc...) during the business creation stage.

\section{Evaluation of business incubator}

BIP1. The installations and infrastructures the incubator offers favour the creation of your own business.

BIP2. The incubator allows for access to high-level tutors and counsellors, which favours the creation of your own business.

BIP3. The incubator allows you to access the experience of successful entrepreneurs and business people, which favours the creation of your own business.

BIP4. The incubator facilitates the access to contact networks that favour the creation of your own business.

BIP5. The incubators facilitates the access to funding sources to create your own business. 
Appendix 2

\begin{tabular}{|c|c|c|c|c|}
\hline Variable & Mean & Standard Dev. & Skewness & Kurtosis \\
\hline INT1 & 4.63 & 0.72 & -2.03 & 3.46 \\
\hline INT2 & 4.36 & 0.96 & -1.57 & 1.79 \\
\hline INT3 & 4.53 & 0.97 & -2.25 & 4.43 \\
\hline INT4 & 4.48 & 0.96 & -1.91 & 2.91 \\
\hline DES1 & 4.74 & 0.73 & -3.78 & 15.71 \\
\hline DES2 & 4.75 & 0.77 & -3.96 & 16.19 \\
\hline DES3 & 4.71 & 0.85 & -3.46 & 11.83 \\
\hline DES4 & 4.49 & 0.86 & -2.05 & 4.54 \\
\hline FEA1 & 3.38 & 1.12 & -0.25 & -0.65 \\
\hline FEA2 & 3.83 & 1.08 & -0.73 & -0.08 \\
\hline FEA3 & 3.52 & 1.07 & -0.31 & -0.42 \\
\hline FEA4 & 4.39 & 0.83 & -10.29 & 0.97 \\
\hline RSK1 & 3.33 & 1.11 & -0.23 & -0.40 \\
\hline RSK2 & 3.33 & 1.17 & -0.10 & -0.82 \\
\hline RSK3 & 3.51 & 1.09 & -0.35 & -0.45 \\
\hline RSK4 & 3.58 & 1.08 & -0.37 & -0.53 \\
\hline SEF1 & 4.59 & 0.69 & -2.06 & 5.55 \\
\hline SEF2 & 4.45 & 0.75 & -1.73 & 4.43 \\
\hline SEF3 & 4.38 & 0.77 & -1.33 & 2.23 \\
\hline SEF4 & 4.19 & 0.85 & -0.91 & 0.57 \\
\hline SEF5 & 4.11 & 0.86 & -0.91 & 0.65 \\
\hline SEF6 & 4.37 & 0.82 & -1.50 & 2.67 \\
\hline SEF7 & 4.31 & 0.85 & -1.31 & 1.83 \\
\hline FCO1 & 3.08 & 1.19 & 0.05 & -0.79 \\
\hline $\mathrm{FCO} 2$ & 3.25 & 1.11 & -0.08 & -0.62 \\
\hline $\mathrm{FCO} 3$ & 3.54 & 1.04 & -0.25 & -0.61 \\
\hline FCO4 & 3.61 & 0.99 & -0.14 & -0.83 \\
\hline FCO5 & 3.73 & 1.04 & -0.70 & 0.09 \\
\hline FCO6 & 3.51 & 1.15 & -0.27 & -0.81 \\
\hline BIP1 & 4.27 & 0.97 & -1.34 & 1.32 \\
\hline BIP2 & 4.36 & 0.96 & -1.61 & 2.29 \\
\hline BIP3 & 4.21 & 1.05 & -1.31 & 0.93 \\
\hline BIP4 & 4.06 & 1.12 & -0.98 & 0.01 \\
\hline BIP5 & 3.79 & 1.27 & -0.82 & -0.41 \\
\hline
\end{tabular}




\section{Appendix 1}

Entrepreneurial Intention

INT1. I have the clear intention to create my own business in less than one year.

INT2. My professional objective is to create my own business in less than one year.

INT3. I am determined to create my own business in less than one year.

INT4. I will do anything possible to create my own business in less than one year.

Desirability

DES1. The idea of creating my own business seems attractive to me.

DES2. The idea of creating my own business really appeals to me.

DES3. Creating my own business would be a huge satisfaction for me.

DES4. My calling is to create my own business.

Feasibility

FEA1. Creating a business in less than one year would be easy for me.

FEA2. It's very feasible to create my own business in less than one year.

FEA3. For me it will be simple to create my own business in less than one year.

FEA4. I'm in a good position to create my own business in less than one year.

Perceived Risk

RSK1. Creating a business is very risky.

RSK2. The probability that the new business fails is very high.

RSK3. There is a lot of uncertainty around the success of a newly created business.

RSK4. A lot of risks exist that are associated with the creation of a new business.

Self-efficacy

SEF1. I believe I am capable of developing innovative ideas and products.

SEF2. I can identify new market opportunities for innovative products and services.

SEF3. I am able to discover new forms of existing products.

SEF4. I am capable of identifying business opportunities with growth potential.

SEF5. I am able to react rapidly to take advantage of business opportunities.

SEF6. I believe I am capable of creating new products that satisfy customers' unsatisfied needs.

SEF7. I can design a plan of action to take advantage of business opportunities.

Facilitating conditions

FCO1. The minimum capital necessary to create a business can be accessed easily.

FCO2. It's easy to find the necessary contacts to be able to take a business forward.

FCO3. It's easy to gain access to experts to develop a new business.

FCO4. I could easily get access to specialised counselling in a sector of specific activity.

FCO5. It's easy to share experiences with successful entrepreneurs in order to develop a business

FCO6. It's easy to access physical spaces (offices, meeting rooms, laboratories, etc...) during the business creation stage.

Evaluation of business incubator

BIP1. The installations and infrastructures the incubator offers favour the creation of your own business.

BIP2. The incubator allows for access to high-level tutors and counsellors, which favours the creation of your own business.

BIP3. The incubator allows you to access the experience of successful entrepreneurs and business people, which favours the creation of your own business.

BIP4. The incubator facilitates the access to contact networks that favour the creation of your own business.

BIP5. The incubators facilitates the access to funding sources to create your own business. 
Appendix 2

\begin{tabular}{|c|c|c|c|c|}
\hline Variable & Mean & Standard Dev. & Skewness & Kurtosis \\
\hline INT1 & 4.63 & 0.72 & -2.03 & 3.46 \\
\hline INT2 & 4.36 & 0.96 & -1.57 & 1.79 \\
\hline INT3 & 4.53 & 0.97 & -2.25 & 4.43 \\
\hline INT4 & 4.48 & 0.96 & -1.91 & 2.91 \\
\hline DES1 & 4.74 & 0.73 & -3.78 & 15.71 \\
\hline DES2 & 4.75 & 0.77 & -3.96 & 16.19 \\
\hline DES3 & 4.71 & 0.85 & -3.46 & 11.83 \\
\hline DES4 & 4.49 & 0.86 & -2.05 & 4.54 \\
\hline FEA1 & 3.38 & 1.12 & -0.25 & -0.65 \\
\hline FEA2 & 3.83 & 1.08 & -0.73 & -0.08 \\
\hline FEA3 & 3.52 & 1.07 & -0.31 & -0.42 \\
\hline FEA4 & 4.39 & 0.83 & -10.29 & 0.97 \\
\hline RSK1 & 3.33 & 1.11 & -0.23 & -0.40 \\
\hline RSK2 & 3.33 & 1.17 & -0.10 & -0.82 \\
\hline RSK3 & 3.51 & 1.09 & -0.35 & -0.45 \\
\hline RSK4 & 3.58 & 1.08 & -0.37 & -0.53 \\
\hline SEF1 & 4.59 & 0.69 & -2.06 & 5.55 \\
\hline SEF2 & 4.45 & 0.75 & -1.73 & 4.43 \\
\hline SEF3 & 4.38 & 0.77 & -1.33 & 2.23 \\
\hline SEF4 & 4.19 & 0.85 & -0.91 & 0.57 \\
\hline SEF5 & 4.11 & 0.86 & -0.91 & 0.65 \\
\hline SEF6 & 4.37 & 0.82 & -1.50 & 2.67 \\
\hline SEF7 & 4.31 & 0.85 & -1.31 & 1.83 \\
\hline FCO1 & 3.08 & 1.19 & 0.05 & -0.79 \\
\hline $\mathrm{FCO} 2$ & 3.25 & 1.11 & -0.08 & -0.62 \\
\hline FCO3 & 3.54 & 1.04 & -0.25 & -0.61 \\
\hline FCO4 & 3.61 & 0.99 & -0.14 & -0.83 \\
\hline FCO5 & 3.73 & 1.04 & -0.70 & 0.09 \\
\hline FCO6 & 3.51 & 1.15 & -0.27 & -0.81 \\
\hline BIP1 & 4.27 & 0.97 & -1.34 & 1.32 \\
\hline BIP2 & 4.36 & 0.96 & -1.61 & 2.29 \\
\hline BIP3 & 4.21 & 1.05 & -1.31 & 0.93 \\
\hline BIP4 & 4.06 & 1.12 & -0.98 & 0.01 \\
\hline BIP5 & 3.79 & 1.27 & -0.82 & -0.41 \\
\hline
\end{tabular}


Figure 1. Shapero-Krueger Model

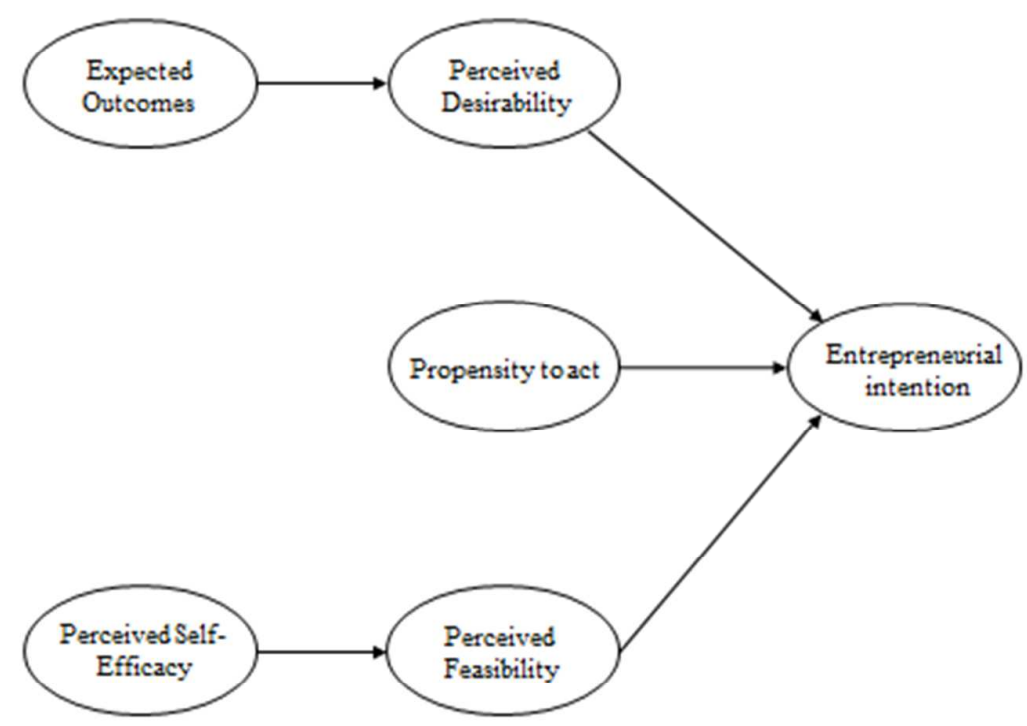

Figure 2. Research Model

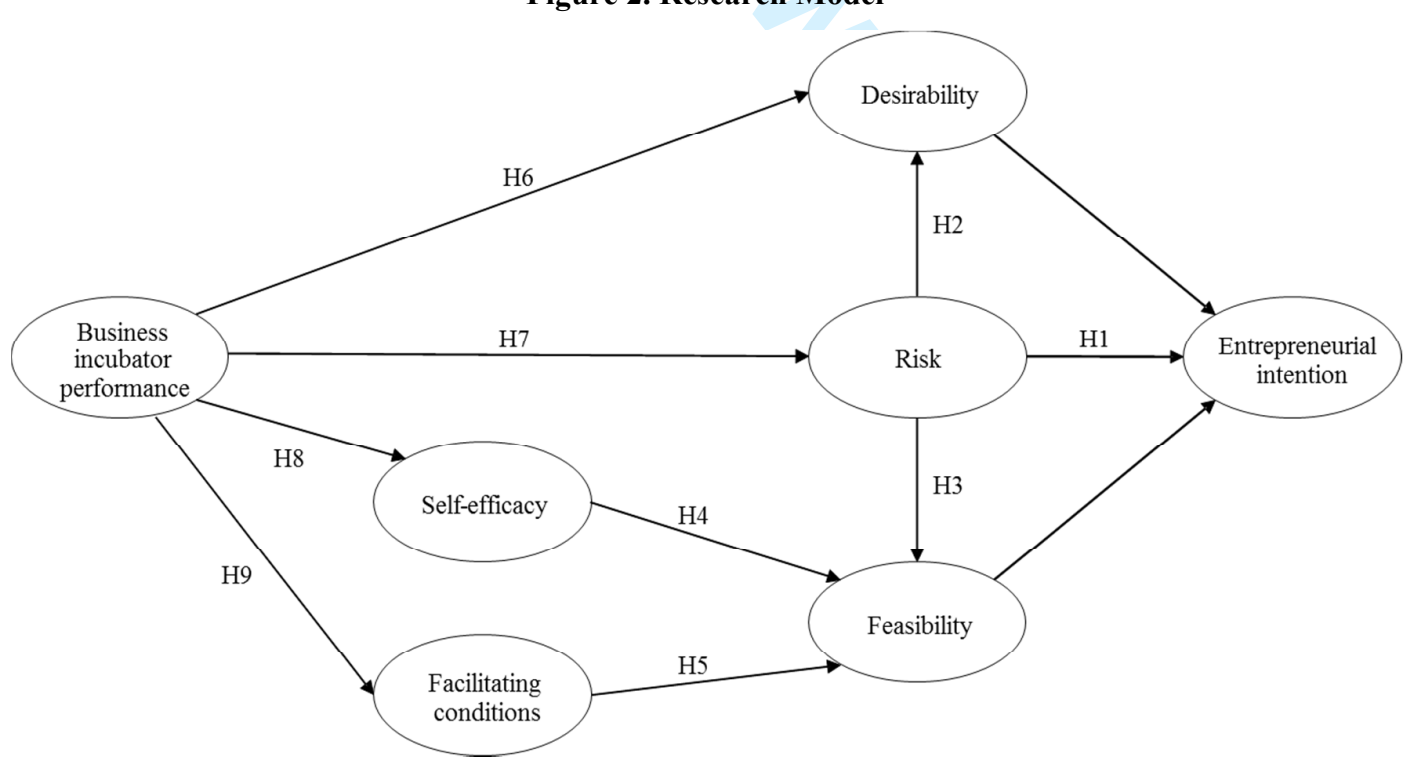


Figure 3. Structural model estimation

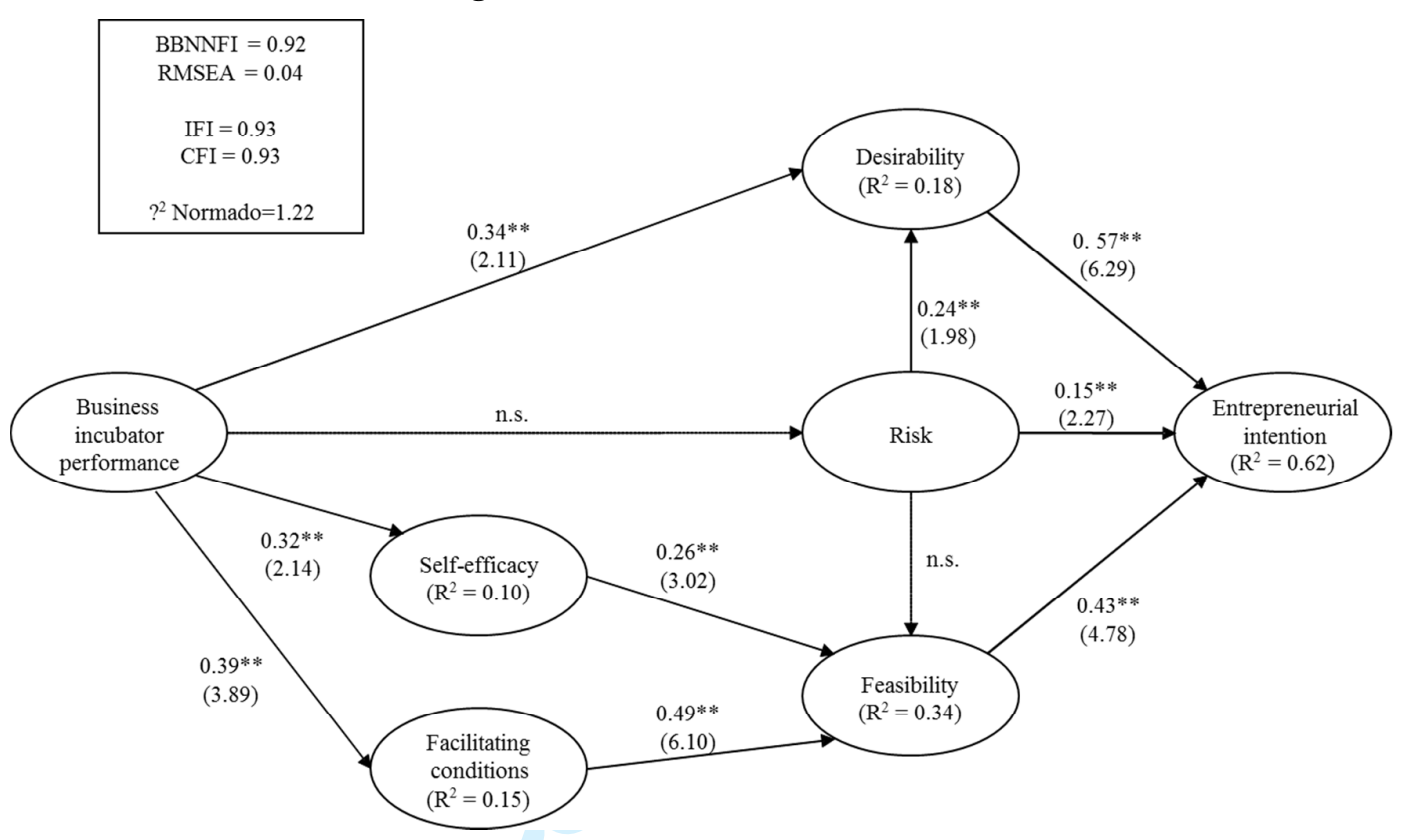


Table 1. Socio-demographic profile of the sample

\begin{tabular}{|l|c|l|c|}
\hline Variable & $\%$ & Variable & $\%$ \\
\hline Gender & & Education field (finished / on course) & \\
\hline Male & 58.3 & Business & 52.5 \\
\hline Female & 41.7 & Engineering & 32.7 \\
\hline Age & & Humanities & 12.3 \\
\hline 24 years or less & 53.1 & Health & 2.5 \\
\hline 25 to 34 years & 27.4 & Entrepreneur in the family & \\
\hline 35 years or more & 19.5 & Yes & 65.9 \\
\hline Education & & No & 34.1 \\
\hline Secondary & 26.1 & Occupation & \\
\hline Graduate & 57.6 & Student & 74.8 \\
\hline Post-graduate & 11.5 & Employee & 18.4 \\
\hline Doctorate & 4.8 & Unemployed & 6.7 \\
\hline
\end{tabular}

Table 2. Confirmatory factor analysis for the model variables

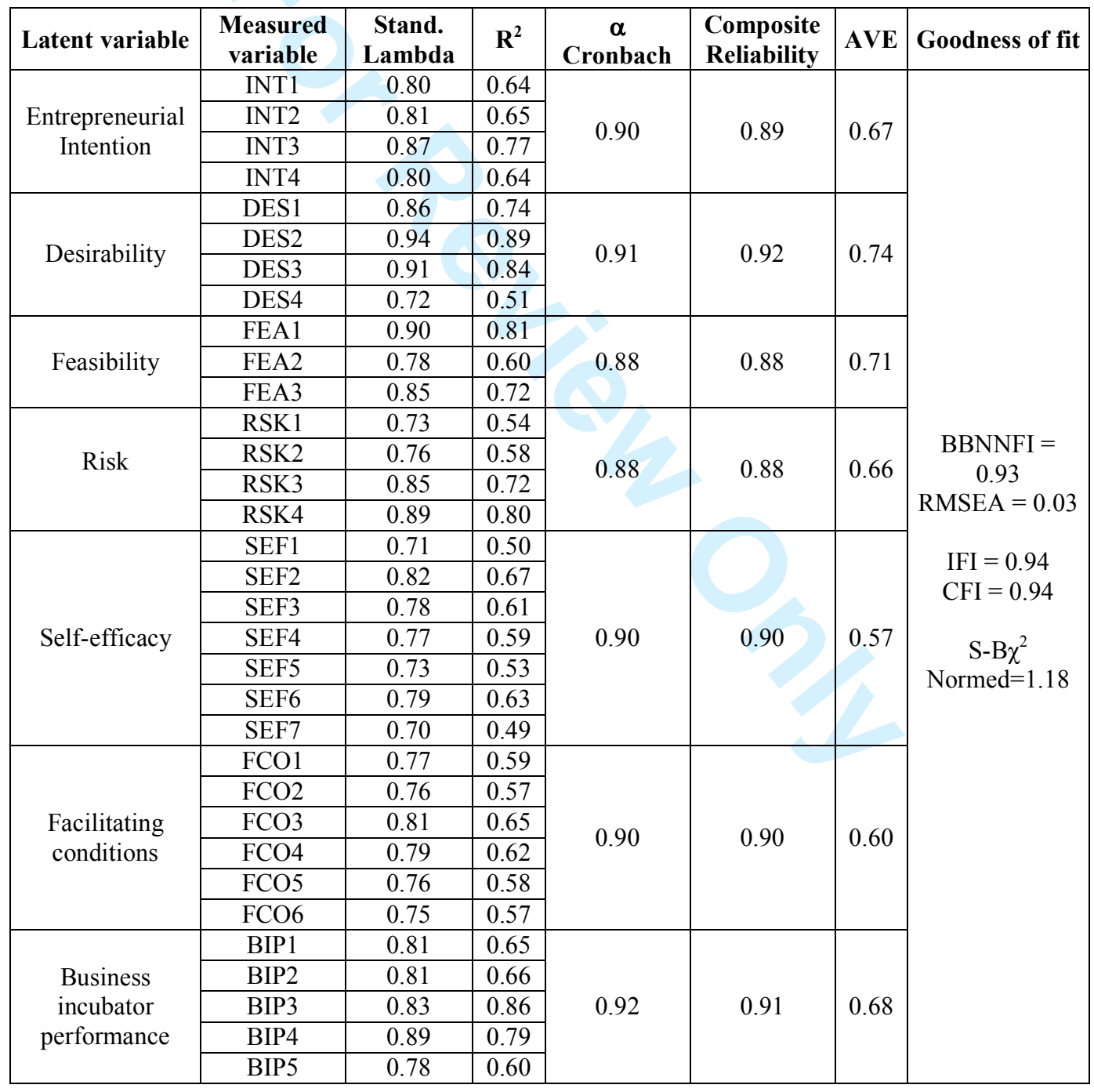


Table 3. Confidence intervals for the correlations between pairs of latent variables

\begin{tabular}{|c|c|c|c|c|c|c|}
\hline $\begin{array}{c}\text { Latent } \\
\text { variable }\end{array}$ & $\begin{array}{c}1 . \\
\text { Entrepreneurial } \\
\text { Intention }\end{array}$ & 2. Desirability & 3. Feasibility & 4. Risk & 5. Self-efficacy & $\begin{array}{c}6 . \\
\text { Facilitating } \\
\text { conditions }\end{array}$ \\
\hline 2. Desirability & $\begin{array}{c}0.693 \\
(0.531 ; 0.855)\end{array}$ & & & & & \\
\hline 3. Feasibility & $\begin{array}{c}0.522 \\
(0.354 ; 0.690)\end{array}$ & $\begin{array}{c}0.227 \\
(-0.005 ; \\
0.459)\end{array}$ & & & & \\
\hline 4. Risk & $\begin{array}{c}0.216 \\
(0.006 ; 0.426)\end{array}$ & $\begin{array}{c}0.251 \\
(-0.007 \\
0.509)\end{array}$ & $\begin{array}{c}-0.193 \\
(-0.405 ; \\
0.019)\end{array}$ & & & \\
\hline $\begin{array}{l}\text { 5. Self- } \\
\text { efficacy }\end{array}$ & $\begin{array}{c}0.388 \\
(0.130 ; 0.646)\end{array}$ & $\begin{array}{c}0.505 \\
(0.217 ; 0.793)\end{array}$ & $\begin{array}{c}0.408 \\
(0.268 ; 0.548)\end{array}$ & $\begin{array}{c}0.050 \\
(-0.164 ; \\
0.264)\end{array}$ & & \\
\hline $\begin{array}{l}\text { 6. Facilitating } \\
\text { conditions }\end{array}$ & $\begin{array}{c}0.308 \\
(0.120 ; 0.496)\end{array}$ & $\begin{array}{c}0.223 \\
(-0.023 \\
0.469)\end{array}$ & $\begin{array}{c}0.568 \\
(0.442 ; 0.694)\end{array}$ & $\begin{array}{c}-0.209 \\
(-0.421 ; \\
0.003)\end{array}$ & $\begin{array}{c}0.312 \\
(0.150 ; 0.474)\end{array}$ & \\
\hline $\begin{array}{l}\text { 7. Business } \\
\text { incubator } \\
\text { performance }\end{array}$ & $\begin{array}{c}0.268 \\
(0.038 ; 0.498)\end{array}$ & $\begin{array}{c}0.335 \\
(0.105 ; 0.565)\end{array}$ & $\begin{array}{c}0.121 \\
(-0.075 \\
0.317)\end{array}$ & $\begin{array}{c}0.025 \\
(-0.247 \\
0.197)\end{array}$ & $\begin{array}{c}0.314 \\
(0.104 ; 0.524)\end{array}$ & $\begin{array}{c}0.391 \\
(0.197 ; 0.585)\end{array}$ \\
\hline
\end{tabular}

Table 4. Shared variances (squared correlations) between pairs of construct

\begin{tabular}{|l|c|c|c|c|c|c|}
\hline & $\begin{array}{c}1 . \\
\text { Entrepreneurial } \\
\text { Intention }\end{array}$ & 2. Desirability & 3. Feasibility & 4. Risk & $\begin{array}{c}\text { 5. Self- } \\
\text { efficacy }\end{array}$ & $\begin{array}{c}\text { 6. Facilitating } \\
\text { conditions }\end{array}$ \\
\hline 2. Desirability & 0.480 & & & & & \\
\hline 3. Feasibility & 0.272 & 0.052 & & & & \\
\hline 4. Risk & 0.047 & 0.063 & 0.037 & & & \\
\hline 5. Self-efficacy & 0.151 & 0.255 & 0.166 & 0.003 & & \\
\hline $\begin{array}{c}\text { 6. Facilitating } \\
\text { conditions }\end{array}$ & 0.095 & 0.050 & 0.323 & 0.044 & 0.097 & \\
\hline $\begin{array}{c}\text { 7. Business } \\
\text { incubator } \\
\text { performance }\end{array}$ & 0.072 & 0.112 & 0.015 & 0.001 & 0.099 & 0.153 \\
\hline
\end{tabular}

